\title{
Analysis of Financial Performance and Sustainability of Microfinance Institutions in Ghana
}

\author{
Emmanuel Atta Anaman', Mavis Pobbi ${ }^{1,2, *}$ \\ ${ }^{1}$ Department of Banking and Finance, School of Business, University of Education, Winneba, Ghana \\ ${ }^{2}$ Department of Accounting, School of Business, University of Education, Winneba, Ghana
}

Email address:

eaanaman@uew.edu.gh (E. A. Anaman),mpobbi@uew.edu.gh (M. Pobbi)

${ }^{*}$ Corresponding author

\section{To cite this article:}

Emmanuel Atta Anaman, Mavis Pobbi. Analysis of Financial Performance and Sustainability of Microfinance Institutions in Ghana. International Journal of Accounting, Finance and Risk Management. Vol. 4, No. 1, 2019, pp. 34-43. doi: 10.11648/j.ijafrm.20190401.14

Received: April 7, 2019; Accepted: May 23, 2019; Published: June 12, 2019

\begin{abstract}
Microfinance has become crucial to Ghana's financial system over the last three decades. They target the financially excluded and poverty stricken population with micro financial products, empowering the poor to create livelihoods for themselves and by so doing contributing towards the economic growth of the country. In recent years, there have been reported cases of the collapse of several microfinance institutions and others facing serious challenges. These series of events signal an ominous situation for the microfinance subsector and the entire financial system for that matter. This study therefore aims at examining the performance of microfinance institutions in Ghana, focusing on three key performance indicators; profitability, liquidity and credit advanced. The study revealed that loan default and interest expenses are the major variables which negatively affect the performance of the MFIs. In ensuring the sustenance of the microfinance subsector of the financial system, the study recommends that, the MFIs should adopt lending methodologies which minimize loan defaults and the Bank of Ghana should be encouraged to strength its regulatory oversight and power to rein in MFIs which offer outrageous rates of return on customers' deposits.
\end{abstract}

Keywords: Microfinance Institutions, Profitability, Liquidity, Credit

\section{Introduction}

The importance of the financial intermediation system in the economy of every nation is something that cannot be underestimated. Indeed it is the financial system that oils the growth of most economies. In developing countries, the role of the microfinance institutions (MFIs) is even more critical because they serve a unique purpose in the sense that they are the institutions which normally provide credit to micro and small scale business/ enterprises especially when it is very difficult or nearly impossible for these concerns to leverage funds from the traditional formal banking channels/ institutions. The relevance of the MFIs in developing countries is underlined by Mahmood et al. when they argue that microfinance is used to support income generating activities that provide exit and/or breakout strategies from poverty and various forms of discrimination [1].

The significance of the MFIs is amplified in the context of the developing countries in the sense that in this part of the world, a huge chunk of the population does not have access to formal banking services and therefore rely heavily on these small loans institutions for variety of services.

Microfinance in the developing world have become the backbone of SME growth and development, driving their momentum and helping create and nurture seasoned entrepreneurs who may eventually blossom into innovators and successful businesses owners and by so doing, open up opportunities through the generation of employment and wealth in their economies. To the extent that MFIs are crucial in dealing with issues of poverty especially in the developing world, their financial performance and sustainability continues to engage the attention of economists/academics as well as policy makers.

Over the last few years, the microfinance sector has been growing tremendously with some countries especially in the developing world achieving $70-100 \%$ expansion in microfinance activities [2]. With such a phenomenal 
expansion of the microfinance subsector of financial services in the developing world, a lot more people particularly the poor, who were previously not having access to any kind of financial services and financially excluded are at least able to access small loans and other micro level financial products. OCSSCo opines that ultimately, microfinance institutions are able to help the poor to escape the vicious cycle of low savings, low investment and low income and put them on the trajectory of low income, microcredit, investment, more income, more investment, more income and more savings [3].

Consistent with trends in the developing world, the microfinance subsector in Ghana is gaining grounds and increasingly becoming a substantial part of the financial intermediation system. From the records of the Bank of Ghana as at July 2016, the number of microfinance institutions which had been licensed to operate was in excess of five hundred (500). Indeed within the microfinance financial space over the last few years, one of the obvious fallouts from rapid expansion of the MFI financial subsector has been the very vigorous intra-industry competition it has engendered, making a lot of the MFIs offer very juicy interest returns on customers' deposits so as to be to get a good market share.

Even though the records in Ghana show an expansion of the microfinance subsector within the last twenty years, there have been reported cases of the collapse of microfinance outlets in the country (examples include R4 and PYRAM, DKM, God is Love, etc.) signaling and highlighting some serious challenges within the sector. In addition to the cases of collapse, instances of microfinance institutions being unable to fulfil the demands of their clientele by way of making available their deposits on requests.

There have been many more reported cases of liquidity problems involving microfinance institutions in Ghana. Again as illustrated earlier, with the entry of more firms into the MFI subsector, a lot more of the MFIs are under pressure and responding to the situation by dramatically increasing their interest expenses and thereby exposing them to the myriad of challenges already enumerated. All of these situations point to the fact that, the microfinance sector in Ghana is under threat and when this situation is allowed to persist, it will eventually undermine Ghana's efforts at reducing poverty.

The current developments within the microfinance sector in Ghana raise various questions as to why a good number of microfinance institutions in the country are in the predicament as identified. Is there a problem with their way of mobilizing funds? Are they offering too generous deposits rates as a way of attracting patronage? How does the interest expense affect the capacity of MFIs to stay in business? What about their approach to extending credit? Do they employ the right mechanisms in the way they assess the credit risks of borrowers? Are the MFIs not able to make the profits as they should? Again what is the level of retrieval of credit extended to clients and how does this affect the operations of the MFI? Are the MFIs being properly supervised?
Prior studies have tended to concentrate on profitability as the basic measure of performance of the MFIs [4-6]. To date the only study which delved into a range of performance indicators but examining them from the macroeconomic and institutional angle is by Imai et al. [7]. However in the present study, we introduce credit advances and liquidity which are also key in assessing the performance of MFIs in Ghana and in addition zero in on the effect of interest expenses as a measure of competition on the performance of MFIs because it does appear that at least in the context of the Ghana, there is an imperative to examine it.

The rest of the paper is proceeds as follows: First a general overview of the major developments within the MFI financial subsector in Ghana is presented. The next Section examines the theoretical issues by reviewing pertinent areas of the literature related to the study. This is followed by a presentation of the study methodology including the empirical model employed in the analysis. Results from the data analysis and discussions of the results are provided next. The paper concludes with the policy implications and suggestions for future studies.

\section{Development in the MFI Subsector in Ghana}

The concept of microfinance in Ghana is something which is not new at all. Indeed it is documented that by 1955, the Catholic missionaries had established the first credit union in northern Ghana and this was complemented by the introduction of the Susu concept into Ghana from Nigeria. Though some form of microfinance activities had long existed in the Ghanaian economy, the formalization of the activities and operations of microfinance institutions did not begin until the 1990s when the microfinance institutions became integrated into the country's financial structure.

In the last two decades the microfinance subsector has contributed tremendously towards the development of the financial sector in the country and hence economic growth in Ghana. This is clearly illustrated by available statistics. From the records of the Ministry of finance, by 2014, there were not less than four hundred MFIs operating in Ghana and the outreach of the MFIs within the period has been improving. To illustrate, we take a brief look at the loan advances. In 2001, total MFI advances in the economy amounted to GhC39.64million, rose to GhC50.97 in 2002 and further to GhC70.63 in 2003 and by 2006 had hit the GhC160.47million mark. In 2007, MFI advances went up more dramatically with the loan portfolio increasing to GHC350.1 million. The expansion of the MFI subsector can be looked at from a different angle, the total number of the MFIs in the books of the Bank of Ghana as registered concerns. For example in 2012, the total number of registered MFI was 216 but by 2016 the Bank of Ghana reported the number topped to 564 , this shows a more than double the figure of 2012.

Despite the expansion of MFI in the country, there have 
emerged within the period some unpalatable situations within the microfinance front. For example, there have been widely reported cases of the collapse of MFIs whilst others are said to be in a very distressed condition. According to MyJoyonline report in May 2018, of the 566 licensed MFIs in March 2018, a total of 211 were either active but distressed or folded up [8]. The Deputy Governor of the Bank of Ghana, Elsie Awadzi further threw light on the enormity of the malaise when she indicated that at the time, more than 200 MFIs were in distress and unable to pay returns that they promised or even the principals of their customers whilst 300 MFIs were on the verge of collapse [9].

\section{Related Literature}

Issues around MFIs have gained widespread attention across the world. This gives the indication that microfinance institutions have become such an important part of the financial system in many countries.

The extent to which the microfinance philosophy addresses a critical need in most of the countries where it has taken root continues to receive significant interests which also trigger vigorous discussions on their operations. This is because inherent in the microfinance model are two principles which appear to be conflicting; endeavoring to reach the mainly rural and urban poor, usually without any access to any kind of financial products with credit lines which help create livelihoods for them and at the same time trying to operate as going commercial concerns with the objective of sustaining their operations so as to be able to meet the needs of their clientele.

The dilemma of MFIs arises out of the fact that a large number of their customers are into very low return activities which therefore make the likelihood of defaults higher. This is because the most common activities which the customers of the MFIs engage in are farming-related activities, small retail businesses and small scale production activities like beads making, earthenware pots fabrication and other activities which require low level technology, most of which do not sufficiently provide high returns to be able to expand as much as they desire.

Against this background, a lot of the academic studies in the field of microfinance have largely focused on issues of sustainability of microfinance schemes. Woolcock stresses that sustainability implies the capacity of the programme to remain financially viable without any domestic subsidies or foreign support and that calls for enough profits to be generated to cover operational costs and thus do away with subsidies [10]. To that effect one important thing which has remained in the policy domain has been the issue of microfinance profitability; profitability in the views of some academics is most critical in making microfinance schemes stay their courses. The central position of profitability is put in context by Aremu et al. when they alluded to the fact that, the existence, growth and survival of a given business depends on its ability to make profits [11]. Indeed in the words of Aremu et al., profit is raison d'etre for any business endeavour [11].

Even though profitability can be described as the most overriding parameter with regards to performance, other aspects like liquidity status of MFIs as well as the ability of the MFI to extend credits to borrowers are also very important in assessing the performance of MFIs. Liquidity here refers to the amount of cash that MFI has on hand to routinely honour its commitments whenever it is called upon to do so. Indeed, liquidity problems for MFIs and any other financial institution can result in a crisis of confidence. It is a problem which when not handled properly can undermine the financial system. Apart from these two, another approach to examining performance of the MFIs is by looking at the amount of credit advanced to MFIs' clientele.

In the literature, a range of factors have been identified and are considered to significantly influence the performance of MFIs; these factors are largely firm specific and include size of the entity, its operating efficiency, interest expense, tax commitments, competition, the non-performing loan portfolio, operating expenses and governance structure among others.

To capture size of MFI, most economists prefer to use the stock of assets of the entity. Normally it is assumed that MFIs with bigger asset base possess deeper and stronger financial muscles which they could leverage to be able to perform better than those which do not. In the literature there is a leaning towards a positive relationship between size of institution and profitability by some researchers whereas others argue that the relationship is rather negative. Some of the authors who canvass the former view are $[12,13,14]$. According to their studies, the larger banks and for that matter financial institutions tend to possess economies of scale which allows them to operate at a lower cost. Other scholars however suggest that bigger banks or financial institutions are rather affected by diseconomies of scale whilst smaller banks are able to operate much more efficiently and are thus more profitable than larger ones [15, $16]$.

Firm's operating efficiency defines the ratio between operating costs and income. It thus shows the relationship between the firm's cost of operations and returns; it derives from its operations. Interest expense has also become important in recent times especially against the background that a lot of microfinance institutions are vigorously devising ways of attracting deposits from its customers. They do so by setting very attractive rates of return on their deposits so that they can attract more and more clients.

Though the MFIs may be able to attract new customers, they may be endangering their profits and liquidity since they have to divert a lot more funds to the paying of interests on deposits on regular basis. Liquidity defines the portion of the firm's assets in cash and which allows financial institutions to create credits. In the opinion of Menicucci et al., a bank with higher liquidity has the ability to create more loans and through that experience increased profits but that they add, could lead to a reduction in credit quality which in turn would negatively affect firm profitability [17]. Apart from 
the factors identified in the literature, some researchers cite operating expense as an institution specific factor which borders on the cost of the operations of the MFI and argue that it is another factor which is considered when discussing the performance of MFIs. The effect of operating expense on performance is rather inconclusive from what studies are available [18, 19].

Non-performing loan portfolio is another major issue that a lot of MFIs have to contend with. Non-performing loan portfolio literally deprives the MFIs of their ability to routinely sustain their operations and by that increase their susceptibility especially as going business concerns. According to Berger and De Young, non-performing loans are usually the result of poor management on the part of managers of financial institutions in relation to the proper loan application evaluation in a lot of cases and weak, ineffective monitoring and control in some other cases [18]. On the demand side however, a number of factors can be identified; the main ones however are the sheer inordinate and conscious unwillingness of borrowers to simply pay back and the misapplication of loan funds through diversion of money making it difficult for the borrower to be able to pay back. Non-performing loans are therefore always a threat to the sustenance of financial institutions.

In the view of other researchers beyond the factors outlines above, interest rates payable on credits and other macroeconomic variables are also strongly argued to affect performance of MFIs. This is canvassed particularly by Balogun and Alimi [19]. Further studies also suggest that there is a procyclical relationship between the performance of the microfinance institutions and the macroeconomic variables and that relationship they believe provides a strong basis for suspecting that it is potentially bidirectional in character [7].

Over the years, various empirical studies have been conducted into identifying the determinants of the profitability of financial institutions and these have largely yielded diverse results. Mersland and Ostrom examined governance and performance of MFIs. Their key objective was to determine how the governance structures and mechanisms of microfinance institutions impinge on their performance. They employed a random effects panel regression and 3SLS method in their analysis. Their results suggest that the governance structures of the MFI have effect on the performance of MFIs but do not significantly influence outreach by the MFIs [5]. Coleman \& Osei endeavored to isolate the MFI characteristics that influence their profitability by particularly investigating the effects of different aspects of governance which affect the profitability and outreach of these institutions. From their analysis, they discovered that board size, board independence, competence of board, the size of the MFI among others significantly influence outreach and profitability of MFIs [6]. Imai et al. set out to study the performance of MFIs from the macroeconomic and institutional perspectives. They constructed a five equation model and using the 3SLS and Fixed Effects Vector Decomposition (FEVD) methods, they found that the performances of the MFIs are positively influenced by both the institutional and macroeconomic factors [7].

Assefa et al. studied the performance and competition of microfinance institutions. Their study was to examine the effect of competition on a range of performance indicatorsoutreach, default rates and efficiency. Employing a linear regression model which related the performance indicators to the various explanatory variables, they conclusively discovered that competition has a negative impact on all the performance indicators and recommended measures which could be instituted to temper down the effects of extreme competition [2]. Abreu et al. in their study of the financial performance of commercial banks across Portugal, Spain, France and Germany established that increased loan ratios have a positive effect on profitability [20]. Crabb \& Keller examined further the impact of lending methodologies by MFIs on the portfolio risk and concluded that different lending methodologies by MFIs tend to have differential impacts on portfolio risks of MFIs [21].

In the study by Janda \& Turbat, the main objective was to evaluate the success of the microfinance concept especially in the "transition" countries in Central Asia, by assessing their financial performance. They used fixed effects panel as well as pooled OLS regression models to execute their analyses and found that the type of lending has impact on the MFI portfolio yield. More specifically, group lending has a positive impact portfolio yield whilst lending to women or women's groups tends to also to increase portfolio yield of MFIs [4].

\section{THEORETICAL FRAMEWORK:}

The behaviours of MFIs have been discussed quite extensively in the literature and various researchers have proffered different perspectives. The most common propositions in the literature however, which are invoked to underpin the behaviours of MFIs are the efficiency hypothesis and the balanced portfolio theory.

In the efficiency hypothesis, it is assumed that the contemporary MFI operates just like any utility maximizing firm and thus sets itself an objective of maximizing profits. To achieve that it systematically endeavour to reduce its unit cost of production relative to its competitors as much as possible and by virtue of that earn higher profits. The higher efficiency it is argued can be as a result of better management practices and or the deployment of improved technologies or by the achievement of economies of scale by the firm. Indeed it is suggested that most of these developments mentioned may be occasioned by competition which from the market perspective always leads to well- functioning markets promoting allocative and productive efficiencies whilst at the same time providing the impetus for the development of new and innovative products. It must however be stressed that there is an anti-competition argument which posits that competition may rather force MFIs to adopt very liberal attitudes with regard to loan screening processes resulting in adverse selection and moral hazards because of the existence of information asymmetries. Again, the liberal attitudes may 
affect MFIs in terms of credit monitoring and loan repayments which effectively undermine their efficiency.

The balanced portfolio theory explains the behaviour of financial institutions to be mostly guided by the imperative of ensuring a good spread of the institution's assets to minimize risks usually as a result of the management body taking prudent decisions to diversify their portfolio holdings and thereby optimize profits especially in relation to the risks profiles of the alternative investment avenues.

\section{Methodology and Date}

\subsection{Methodology}

This study adopts a predominantly quantitative approach in identifying the factors which significantly affect performance of the microfinance institutions. We adopted the method employed in most of the studies relating to banks, defining each performance indicator as a function of a number of bank specific explanatory variables.

In our analysis, we concentrate on three different aspects of performance; profitability, liquidity and amount of credit created by the MFIs.

We start by modelling each performance indicator econometrically by assuming a linear relationship between it and the other explanatory variables. This is consistent with a lot of the previous studies like [4, 2, 22].

$$
Y_{i t}=\alpha_{i t}+\beta_{i t} X_{i t}+\mu_{i t}
$$

Where $Y_{i t} \mathrm{~s}$ represent the a matrix of the performance variable of ith MFI measured at time t, $X_{i t}$ defines each explanatory variable taken with respect to the ith MFI at time $\mathrm{t}$ while $\mu_{i t}$ is the random disturbance term normally distributed.

Based on the above econometric equation, we define three specific performance indicator functions which are estimated separately. These are:

$$
\begin{gathered}
R O A_{i t}=\alpha_{i t}+\beta_{1} P n_{i t}+\beta_{2} T x_{i t}+\beta_{3} O p_{i t}+\beta_{4} I n T_{i t}+\beta_{5} S z_{i t}+\beta_{6} C n_{i t}+\beta_{1} L d_{i t}+\varepsilon_{i t} \\
L d_{i t}=\alpha_{i t}+\lambda_{1} P n_{i t}+\lambda_{2} T x_{i t}+\lambda_{3} O p_{i t}+\lambda_{4} I n T_{i t}+\lambda_{5} S z_{i t}+\lambda_{6} C n_{i t}+\varepsilon_{i t} \\
c r_{i t}=\alpha_{i t}+\delta_{1} P n_{i t}+\delta_{2} T x_{i t}+\delta_{3} O p_{i t}+\delta_{4} I n T_{i t}+\delta_{5} S z_{i t}+\delta_{6} L d_{i t}+\varepsilon_{i t}
\end{gathered}
$$

Since our regression model is based on panel data, we test the data to determine whether it is the fixed or the random effects which fits the model. We perform this by employing the Hausman test to determine whether the random or fixed effects assumptions are the ones to uphold in our analysis.

In our study, we test the following hypotheses;

Hypothesis 1: Loan default does not have any significant impact on performance of MFIs.

Hypothesis 2: Interest expense does not significantly influence the performance of MFIs.

Hypothesis 3: The size of the MFI has no effect on the performance of the MFIs.

As a precursor to the estimation of the three equations, we perform correlation analysis to determine the degree of association between the variables. The essence of is to ensure that we avoid the problem of multicollinearity in the estimations, taking a cue from the studies by Kennedy, emphasizes were made to the effect that, a high correlation between variables may likely jeopardize the integrity of the results in regression analysis [23]. In the words of Kennedy, multicollinearity becomes a problem when correlation coefficients exceed 0.8 in a given model [23].

In the model above, ROA, return on assets is used to represent profitability, whilst $\mathrm{Ld}$ and $\mathrm{Cr}$ respectively denote liquidity of the MFI and the quantum of credit extended within the $\mathrm{t}^{\text {th }}$ period, Pn defines non-performing loan portfolio, Tx is amount of tax paid by the firm, $\mathrm{Sz}$ describes the size of MFI proxied by total assets of the MFI, Op represents operational expenses whilst InT defines the interest expense.

In the table below, we set up the expected relationship between each dependent variable and its corresponding

\begin{tabular}{|c|c|c|}
\hline Variable & Description & Expected Impact \\
\hline \multicolumn{3}{|c|}{ *Equation 1} \\
\hline \multicolumn{3}{|c|}{ Dependent variable } \\
\hline ROA & Return on Assets (Profitability) & \\
\hline \multicolumn{3}{|c|}{ Explanatory variables } \\
\hline $\mathrm{Pn}$ & Non-performing loan & - \\
\hline $\mathrm{Cr}$ & Amount of credit extended & $+/-$ \\
\hline $\operatorname{InT}$ & Interest expense & - \\
\hline $\mathrm{Sz}$ & Size of MFI & + \\
\hline $\mathrm{Tx}$ & Amount of tax paid & $+/-$ \\
\hline $\mathrm{Ld}$ & Liquidity & $+/-$ \\
\hline \multicolumn{3}{|c|}{ Equation 2} \\
\hline \multicolumn{3}{|c|}{ Dependent variable } \\
\hline $\mathrm{Ld}$ & Liquidity & \\
\hline \multicolumn{3}{|c|}{ Explanatory variables } \\
\hline
\end{tabular}
explanatory variables, based on the predominant views/findings in the literature.

Table 1. Definition of variables and their a priori expectations. 


\begin{tabular}{lll}
\hline Variable & Description & Expected Impact \\
\hline $\mathrm{Tx}$ & Amount of tax paid & - \\
$\mathrm{InT}$ & Interest expense & - \\
$\mathrm{Op}$ & Operational expenses & - \\
$\mathrm{Cr}$ & Amount of credit extended & - \\
$\mathrm{Sz}$ & Size of MFI & + \\
Equation 3 & & \\
Dependent variable & & \\
$\mathrm{Cr}$ & Amount of credit extended & \\
Explanatory variables & & - \\
$\mathrm{Pn}$ & Non-performing loan & - \\
$\mathrm{Tx}$ & Amount of tax paid & + \\
$\mathrm{Ld}$ & Liquidity & $+/-$ \\
$\mathrm{Op}$ & Operational expenses & - \\
$\mathrm{InT}$ & Interest expense & + \\
$\mathrm{Sz}$ & Size of MFI & \\
\hline
\end{tabular}

\subsection{Data}

Obtaining data from microfinance institutions in a developing country such as Ghana is a very daunting task especially in these times when a lot of MFIs are having challenges and so in this study, we relied on those MFIs who were prepared to provide the relevant data that we solicited via various reports and documentation.

In all we obtained data from 42 MFIs across the country and these were the MFIs who made available consistent records of their operations for the last five years 2013-2017.

\section{Estimation Results}

We begin the estimations in the study by providing useful information about the behaviours of the variables. We do this by presenting the summary statistics of both the dependent and explanatory variables in the model. In the table below, we report the summary statistics for the various variables.

Table 2. Descriptive Statistics.

\begin{tabular}{|c|c|c|c|c|c|}
\hline Variable Mean & & Minimum & Maximunm & Standard Deviation & $\mathbf{N}$ \\
\hline ROA & 0.1531 & -0.8799 & 0.7886 & 0.4123 & 210 \\
\hline $\mathrm{Cr}$ & 0.1495 & -0.8876 & 0.8113 & 0.3681 & 210 \\
\hline $\mathrm{Ld}$ & 0.4261 & 0.0334 & 0.6716 & 0.1287 & 210 \\
\hline $\mathrm{Tx}$ & 0.0813 & 0.0052 & 0.1023 & 0.1157 & 210 \\
\hline InT & 0.3669 & 0.0075 & 0.9871 & 0.1415 & 210 \\
\hline Op & 0.1012 & 0.0299 & 0.2876 & 0.0909 & 210 \\
\hline $\mathrm{Pn}$ & 0.3117 & 0.1091 & 0.5783 & 0.2136 & 210 \\
\hline
\end{tabular}

Source: Author's calculations using field data.

From the summary statistics, we observe a significant divergence between the maximum and minimum values for profitability and the amount of credit advanced. This is reflected in their standard deviations. The average profit from the summary above is 0.1531 which indicates low profit levels among the MFIs. Average credit advanced is also very low signaling that the MFIs are not doing well in relation to loan advances to clients. However in the period under study liquidity on the average is quite high. Indeed comparing with other variables, liquidity recorded the highest average. This is followed by the interest expense variable with the average of
0.3669 which means that a good chunk of resources went into settling interest commitments. The average value for the bad debt portfolio is 0.3117 even though the standard deviation is 0.2136 . This shows that the default rate is quite high and the level of default appear to be a bit concentrated around the mean default rate. From the calculated values, it is also evident that the average interest expense is higher the operating expenses. This illustrates a situation where

The MFIs spent more on the average on interest payments than they did for the operations.

Table 3. Correlation Matrix.

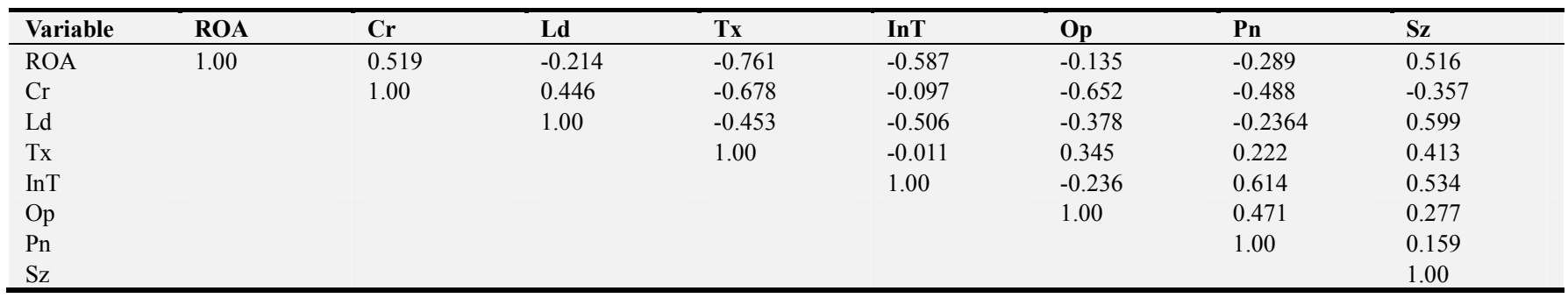

Source: Author's estimations based on the data. 
The correlation coefficients define the level of association between each pair of variables in our variable set and as underlined earlier, these values help us diagnose whether or not there exist multicollinearity issues in our data set. Gleaning the correlation estimates, the highest positive coefficient is 0.614 and therefore setting the correlation coefficients against the rule of the thumb proposed by
Kennedy, we are sure that we would not encounter any issues of collinearity in our regression estimations [23].

Against this background, we enter our variables into the relevant regression equations and proceed to report the results from the analysis which is presented in the table below.

Table 4. Fixed Effects regression results.

\begin{tabular}{|c|c|c|c|c|}
\hline Variable & Estimated coefficient & Std. Error & t-value & Significance level \\
\hline Equation 1 & \multicolumn{4}{|c|}{ Dependent Variable: Profitability (ROA) } \\
\hline $\mathrm{Pn}$ & -3.977 & 0.070 & -56.814 & $0.000 * * *$ \\
\hline $\mathrm{Cr}$ & 1.349 & 0.270 & 5.210 & $0.000 * * *$ \\
\hline InT & -1.584 & 0.626 & -2.532 & $0.005 * * *$ \\
\hline $\mathrm{Sz}$ & 2.613 & 1.095 & 2.386 & $0.021 * *$ \\
\hline Op & 0.997 & 0.503 & -1.982 & $0.047 * *$ \\
\hline $\mathrm{Tx}$ & -4.978 & 1.459 & -3.412 & $0.001 * * *$ \\
\hline Constant & 1.964 & 0.712 & 2.766 & $0.004 * * *$ \\
\hline $\mathrm{R}^{2}$ & 0.445 & & & \\
\hline Adj $R^{2}$ & 0.391 & & & \\
\hline Hausman Statistic & 20.01 & & & \\
\hline Sig level & 0.002 & & & \\
\hline Durbin Watson Statistic & 1.963 & & & \\
\hline Equation 2 & \multicolumn{4}{|c|}{ Dependent Variable: Liquidity (Ln) } \\
\hline $\mathrm{Cr}$ & -1.035 & 0.530 & -1.953 & $0.051 *$ \\
\hline InT & -2.032 & 1.033 & -1.967 & $0.049 * *$ \\
\hline $\mathrm{Sz}$ & 0.506 & 0.241 & 2.100 & $0.034 * *$ \\
\hline Op & 0.387 & 0.825 & 0.469 & 0.561 \\
\hline $\mathrm{Tx}$ & -0.294 & 0.174 & -1.687 & 0.253 \\
\hline Constant & 0.788 & 0.352 & 2.241 & $0.026 * *$ \\
\hline $\mathrm{R}^{2}$ & 0.564 & & & \\
\hline Adj $R^{2}$ & 0.528 & & & \\
\hline Hausman Statistic & 25.03 & & & \\
\hline Sig level & 0.001 & & & \\
\hline Durbin Watson Statistic & 1.899 & & & \\
\hline Equation 3: & \multicolumn{4}{|c|}{ Dependent Variable: Amount of Credit Advanced (Cr) } \\
\hline $\mathrm{Pn}$ & -12.086 & 2.211 & -5.465 & $0.000 * * *$ \\
\hline InT & -3.108 & 1.232 & -2.523 & $0.012 * *$ \\
\hline $\mathrm{Sz}$ & 1.185 & 0.268 & 4.427 & $0.000 * * *$ \\
\hline Op & 0.821 & 0.413 & 1.989 & $0.042 * *$ \\
\hline Constant & -0.883 & 0.448 & -1.969 & $0.050 * *$ \\
\hline $\mathrm{R}^{2}$ & 0.619 & & & \\
\hline Adj $R^{2}$ & 0.583 & & & \\
\hline Hausman Statistic & 31.26 & & & \\
\hline Sig level & 0.000 & & & \\
\hline Durbin Watson Statistic & 2.104 & & & \\
\hline
\end{tabular}

The symbols $* * *, * *$ and $*$ above denote significance at $1 \%, 5 \%$ and $10 \%$ respectively.

Source: Field Data.

From the regression results, the equations appear well behaved with appreciable levels of explanatory power. The explanatory powers of the profitability, liquidity and amount of credit equations are measured at $39 \%, 53 \%$ and $58 \%$ respectively. Indeed the explanatory powers of the models are generally very reliable because the divergence between the $R^{2}$ and Adj $R^{2}$ in each of the three equations is minimal. Therefore the estimated $R^{2}$ and $\mathrm{Adj} \mathrm{R}^{2}$ indicate that explanatory variables in the various equations are reasonably related to their respective dependent variables.
The Hausman statistics for all the three equations reject the null hypothesis that random effects fit the models in favour of the alternative that the fixed effects apply in all the equations. The presentation of the fixed effects regression results above is thus informed by that finding.

Considering the results for profitability, it is clear that most of the explanatory variables have significant effect on profitability. The results show that the variables with greatest impact are non-performing loan and tax. Specifically, a unit increase in the tax paid by MFIs tends to lead to about five 
units decline in profit. In the case of non-performing loans, a unit increase in the level of non-performing loans results in about four units decline in profitability. Thus this result falls in line with some other previous studies, such as [24, 17]. This is generally expected because loan default has the tendency of reducing the flow of funds for MFIs to be able to continue their operations.

The level of credit advanced, from the regression results positively impacts on profitability. The estimated parameter for credit advanced is 1.349 which implies that a $100 \%$ increase in credit advanced triggers about $135 \%$ increase in profitability.

The estimated effect of parameter for size of the MFI on profitability is largely consistent with what pertains in the literature. More succinctly, the size of the MFI is found from our regression results to have a positive influence on the profitability of the MFI. Studies carried out by Menicucci et al. and Gul et al found similar results $[17,25]$. Our results appear to confirm the argument by some researchers that a larger sized financial institution may benefit from economies of scale which could allow the institution to increase its performance. In real terms from the estimated model, a unit increase in the size of MFI precipitates a 2.6 units increase in the profit of the MFI.

The interest expense variable returns the expected negative sign meaning that an increase in interest expense results in a reduction in the profit of the MFI. In the estimated equation, a $100 \%$ increase in interest expense leads to just under $160 \%$ decline in profitability. This coincides with the view that increased interest payments as a strategy by MFIs to be competitive have a debilitating effect on the profitability of the MFIs.

Operating expenses from the estimated equation, also impacts negatively on profitability of MFIs. In real terms, a unit increase in operating expenses tends to trigger a 0.99 units decline in the profitability of the MFIs. This finding falls in line with that of some previous studies.

The only variable which does not have significant impact on profitability is liquidity. This is a little surprising in view of the fact a good number of the previous studies have reported significant impact on profitability. With respect to the liquidity equation, two variables are found not to be significant; these are operating expenses and taxes. Surprisingly however, the non-performing loan is estimated to have a positive effect on liquidity. From the results above, a unit increase in non-performing loans also causes an increase in liquidity by 1.6 units. This contrasts with Boateng et al. who found a negative effect of non-performing on liquidity [26]. On the other hand, credit advances and interest expense both have a negative significant effect on liquidity. Whilst a unit increase in credit advances triggers 1.03 units decline in liquidity, a $100 \%$ increase in interest expense leads to more than $200 \%$ reduction in liquidity of MFIs.

The estimated effect of the size of the MFI on liquidity coincides with the expectation. In our regression results, we observe that the measured coefficient for size is 0.5 meaning that generally a $1 \%$ increase in the size of the MFI causes about $0.5 \%$ increase in liquidity.

In the credit equation, non-performing loans portfolio and interest expense predictably have a negative effect. Indeed non-performing loan portfolio has the most profound influence on credit advances with a unit increase in the loans default precipitating a whooping decline of a little over 12 units. On the part of interest expense, a 100\% increase calls forth a $301 \%$ decline in the credit advances. However, both liquidity and size of MFI have a significantly positive effect on credit advances at less than $1 \%$. Whilst a unit increases in liquidity triggers 1.03 units increment in credit advances, the same unit increase in size leads to about 1.19 units increase in credit advances.

\section{Conclusions and Policy Recommendations}

In Ghana, the role of the MFIs has gained far more importance than it used to because the operations of MFIs in the last twenty-five years, have widened the scope of financial inclusion in the economy particularly by reaching people especially the very poor who were previously financially excluded with some financial products. In view of the utmost importance of MFI the study has endeavored to focus on the determinants of the performance of the MFIs, concentrating on three performance variables; profitability, liquidity and credit advances. From the analysis, we have confirmed that loan default negatively influences the performance of MFIs in Ghana.

This has the tendency of undermining the efforts of the MFIs in being able to service the largely financially excluded very poor in society. One plausible reason for the high defaults may be that the MFIs have very little information on their clientele which is mostly found in the informal sector. In addition the credit application screening processes in the MFIs may not be up to scratch and this exacerbates the probability of default on the part of clients. Again most MFIs in Ghana employ the individual credit model which further aggravates the problem of loan recoveries. To stem the problem of default, it is recommended that the MFIs adopt the lending models employed in other jurisdictions which focus on groups rather than individuals in line with proposition by Armendariz and Morduch [27]. This could help reduce risk encountered by the MFIs, ultimately help deal with the effects of the problems enumerated and by that bring down defaults and by extension increase the performance of the MFIs.

From our analysis, we have also determined that interest expense depresses performance of the MFIs. It is to be stressed that interest expense has become hugely important in the non-banking financial sector especially MFIs which offer more competitive rates of return on customers' deposits as a way of outdoing other MFIs. This has arisen out of the establishment of many more MFIs in the country leading to intense competition within the subsector. Thus interest on deposits has become a major instrument for competition 
within the MFIs. In our view, the resolution of this problem would require some regulatory actions. The Bank of Ghana which has oversight and regulatory functions over these institutions would have to more closely monitor these MFIs especially in the area of interest rates on deposits by customers and crack the whip if necessary in order to prevent possible collapse of more MFIs as result of losses and also protect customers' deposits. This is because abnormal or excessive interest on deposits can gravely affect the sustainability of the microfinance subsector which would then be a setback to the country in terms of reaching the unbanked and fostering financial inclusion. Indeed one strategy which the central bank can employ to closely supervise the MFIs is by establishing a special purpose institution on the lines of ARB Apex Bank which was set up to monitor the rural banks in Ghana to be able to specifically and closely supervise the MFIs. This would help in plugging the loopholes in the legal and regulatory framework used to manage and administer the microfinance subsector in the country. Another remedy may be defining strict governance regimes for MFIs to follow, a move which may keep MFIs in check.

We also found out that the size of the MFI represented by the total assets of MFIs relates positively with performance and this means that one way that MFIs can ensure sound performance is to guarantee a strong asset base. To make sure that this is adhered to, the BOG should continuously assess the assets base of the MFIs by regularly embarking on rigorous assets quality assessments to keep MFI from errant behaviours and on their toes to do the right things.

In summing up, we acknowledge that our study would have been a lot more better, if we had obtain an appreciable longer series in terms of the number of years covered. This in our view would have enabled us to employ a dynamic panel model to assess the relevant relationships. We suggest therefore, for future study to use longer series in terms of number of years, as a way of moving forward the frontiers of academic research and for that matter knowledge in this domain.

\section{References}

[1] Mahmood, S., Hussain, J. \& Matlay, H. Z., (2014). Optimal microfinance loan size and poverty reduction amongst female entrepreneurs in Pakistan. Journal of Small Business and Enterprise Development, 2 [2], 231-249.

[2] Assefa, E., Hermes, N., \& Meesters, A., (2010). Competition and Performance of microfinance institutions. University of Groningen, mimeo.

[3] OCSSCO (2002), cited in Yirsaw, A (2008). The performance of microfinance institutions in Ethiopia: A case of six microfinance institutions in Ethiopia. A Published Thesis.

[4] Janda, K., \& Turbat, B., (2013). Determinants of the financial performance of microfinance institutions in Central Asia. Post-Communist Economies, 25 (4), 557-568.

[5] Mersland, R., \& Strom, O. (2009). Performance and corporate governance in microfinance institution. Journal of Banking and Finance, 33, 662-669.

[6] Coleman, A. K., \& Osei, K. A., (2008). Outreach and profitability of microfinance institutions. Applied Financial Economics, 23 (9), 767-782.

[7] Imai, K., Gaiha, R., Thapa, G., Annim, S., K., \& Gupta, A. (2011). Performance of the microfinance institutions: a macroeconomic and institutional perspective. The University of Manchester, Economics Discussion Paper Series, EDP1116.

[8] Myjoyonline (2018). Retrieved from http//www.myjoyonline.com/business/2018/may/microfinance -in-ghana-mission-impossible.

[9] Ghanaweb (2018). Retrieved from https//www.ghanaweb.com/GhanahomePage/business/GhanaCentral Bank.

[10] Woolcock, M., J., Y., (1999). Learning from failures in microfinance: what unsuccessful cases tell us how group based programs work. American Journal of Economics and Sociology, 58 (1), 17- 42.

[11] Aremu, M., A., Ekpo, I., C., \& Mustapha, A., M., (2013). Determinants of banks profitability in a developing economy: evidence from Nigerian banking industry. Interdisciplinary Journal of Contemporary Research in Business, 4 (9), 17-28.

[12] Saeed, M., S. (2014). Bank related and macroeconomic factors affecting bank profitability: a case of the United Kingdom. Research Journal of Finance and Accounting, 5 (2), 42-50.

[13] Aip, A., Ban, U., Demirgines, K., \& Kilik, S., (2010). Internal determinants of profitability in Turkish banking sector. Istanbul Stock Exchange Review, 12 (46), 1-14.

[14] Degan, M., (2013). Does firm size affect firm profitability? Evidence from Turkey. Research Journal of Finance and Accounting, 4 (4), 53-59.

[15] Kwan, S., \& Eisenbeis, R., A., (1997). Bank risk, capitalization and operating efficiency. Journal of financial services Research, 12 (2), 117-131.

[16] Vander Vennet, R., (2002). Cost and profit dynamics in financial conglomerates and universal banks in Europe.' Journal of Money, Credit and Banking, 34 (1), 254-282.

[17] Menicucci, E., \& Paolucci (2016). The determinants of bank profitability: empirical evidence from European banking sector. Journal of Financial Reporting and Accounting, 14 (1), 86-115.

[18] Berger, A., N., \& De Young, R., (1995). Problem loans and lost efficiency in commercial banks. Centre for Financial Institutional Working Papers, Wharton School Centre for Financial Institutions - University of Pennsylvania.

[19] Balogun E., D., \& Alimi, A., (1988). Loan delinquency among small farmers in developing countries: a case study of small farmers' credit programme in Lagos State of Nigeria. $C B N$ Economic and Financial Review.

[20] Abreu, M, \& Mendes, Y., (2002). Commercial Bank interest margins and profitability: evidence from EU countries. University of Porto Working Paper Series, (122).

[21] Crabb, P., R., \& Keller, T., (2006). A test of portfolio risk in microfinance institutions. Faith and Economics, 47 (48), 25-39. 
[22] Garcia-Herrero, A., Gavila, S., \& Santabarbara, D., (2009). What explains the profitability of Chinese Banks? Journal of Banking and Finance, 33 (11), 2080-2092.

[23] Kennedy, P. (2008). A Guide to Econometrics. (6 ed.). USA: Blackwell Pub Moulden Mass Oxford.

[24] Gul, S., Ishad, F., \& Zaman, K. (2011). Factors affecting bank profitability in Pakistan. The Romanian Economic Journal, 14 (39), 61-87.
[25] Boateng, F., G., Notey, S., Barnie, J., A., Dwumah, P., Acheampong, M., \& Ackom-Sampeng, E., (2016). Collapsing microfinance institutions in Ghana: an account of how four expanded and imploded in the Ashanti Region. International Journal of African Development, 3 (2).

[26] Armendariz de Aghion, B., \& Murduch, J. (2005). The Economics of Microfinance. Cambridge, MA: The MIT Press. 